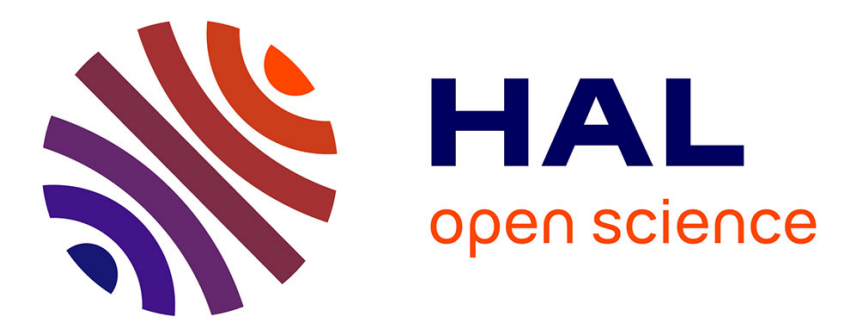

\title{
Prediction of soil water retention properties after stratification by combining texture, bulk density and the type of horizon
}

Hassan Al Majou, Ary Bruand, Odile Duval, Christine Le Bas, A. Vautier

\section{To cite this version:}

Hassan Al Majou, Ary Bruand, Odile Duval, Christine Le Bas, A. Vautier. Prediction of soil water retention properties after stratification by combining texture, bulk density and the type of horizon. Soil Use and Management, 2008, 24 (4), pp.383-391. 10.1111/j.1475-2743.2008.00180.x . insu-00860817

\section{HAL Id: insu-00860817 https://hal-insu.archives-ouvertes.fr/insu-00860817}

Submitted on 11 Sep 2013

HAL is a multi-disciplinary open access archive for the deposit and dissemination of scientific research documents, whether they are published or not. The documents may come from teaching and research institutions in France or abroad, or from public or private research centers.
L'archive ouverte pluridisciplinaire HAL, est destinée au dépôt et à la diffusion de documents scientifiques de niveau recherche, publiés ou non, émanant des établissements d'enseignement et de recherche français ou étrangers, des laboratoires publics ou privés. 
Prediction of soil water retention properties after stratification by combining texture, bulk density and the type of horizon

\author{
H. Al Majou ${ }^{1,2}$, A. Bruand ${ }^{1}$, O. Duval ${ }^{3}$, C. Le Bas ${ }^{4}$, A.Vautier $^{5}$ \\ 1 Université d'Orléans, CNRS/INSU, Université François Rabelais Tours, Institut des
} Sciences de la Terre d'Orléans (ISTO), Campus Géosciences, 1A Rue de la Férollerie, 45071 Orléans Cedex 2, France

${ }^{2}$ Département des Sciences du Sol, Faculté Agronomique, Université de Damas, PO Box 30621, Damas, Syrie

${ }^{3}$ INRA, UR 0272 Science du sol, Centre de Recherche d'Orléans, BP20619, 45166 Olivet Cedex, France.

${ }^{4}$ INRA, Unité INFOSOL, Centre de Recherche d'Orléans, BP20619, 45166 Olivet Cedex, France.

${ }^{5}$ Chambre d'Agriculture de la Nièvre, 25 boulevard Léon Blum - BP 80 - 58028 Nevers Cedex, France

Abstract

Among the numerous pedotransfer functions (PTFs) published, class-PTfs have received little attention because their accuracy is often considered as limited. However, recent studies show that performance of class-PTFs can be similar to the more popular continuous-PTFs. In this study, we compare the performance of PTFs that were derived from a set of 456 horizons collected in France grouped by combinations of texture, bulk density and type of horizon (topsoil and subsoil). The performance of these class-PTFs was validated against water retained at -33 and $-1500 \mathrm{kPa}$. Our results show that the best performance was obtained with 
class-PTFs that used both texture and bulk density (texture-structural class-PTFs). They showed also that incorporation of horizon type into the PTF did not improve prediction performance. Comparison of performance at -33 and $-1500 \mathrm{kPa}$ showed very little difference, thus indicating no bias according to the value of water potential. Finally, the class-PTFs developed are well suited for predicting water retention properties at continental and national scales because only very basic soils data is available at these scales. A map of the available water capacity (AWC) was established for France using the 1:1 000000 Soil Geographical Database of France and an averaged AWC of $104 \mathrm{~mm}$ was computed for France.

Keywords: Class pedotransfer function, prediction bias, prediction precision, available water capacity, digital soil mapping

\section{INTRODUCTION}

Pedotransfer functions (PTFs) use basic soil properties that are relatively easily available to less frequent and more difficult to measure soil properties such as hydraulic ones (Bouma and van Lanen, 1987). Many are continuous pedotransfer functions (continuous-PTFs) developed over the last three decades and are empirical regression functions relating hydraulic parameters to basic soil properties including texture, organic matter content and bulk density (e.g. Bastet et al., 1999; Wösten et al., 2001; Pachepsky et al., 2006). Thus continuous-PTFs enabling the prediction of water content at particular water potentials (Rawls et al., 1982 \& 2004) or the estimation of the parameters of models of the water retention curve (Vereecken

et al., 1989; Bruand et al., 1994; Leenhardt, 1995; Minasny et al., 1999; Wösten et al., 2001; Cresswell et al., 2006; Tranter et al., 2007). 
In addition to the development of continuous-PTFs, class pedotransfer functions (classPTFs) were also developed (Wösten et al., 1995; Pachepsky et al., 2003; Rawls et al., 2003). Most class-PTFs provide class average water contents at particular water potentials or one average water retention curve for every textural class (e.g. Nemes et al, 2001; Nemes, 2002; Bruand et al., 2003 \& 2004). They received little attention because their accuracy was considered limited (Wösten et al., 1995). Due to the large range in particle size distribution, clay mineralogy, organic matter content and structural development within each texture class, water retention properties for individual soils vary considerably (Wösten et al., 1999). ClassPTFs are easy to use given that they require little soil information and are well suited for predicting water retention properties at continental and national scales because only very basic soils data is available at these scales (Wösten et al. 1995; Lilly et al., 1999; Wösten et al. 1999; Nemes et al., 2003).

Several studies provide information on the performance of continuous-PTFs (Minasny et al., 1999; Wösten et al., 2001; Cornelis et al., 2001; Donatelli et al., 2004) and class-PTFs (Pachepsky and Rawls, 1999; Wösten et al., 2001; Ungaro et al., 2005). However, there are very few studies comparing the performance of continuous- and class-PTFs when applied to the same dataset (Wösten et al., 1995). Al Majou et al. (2007) compared the performance of class- and continuous-PTFs and showed that they perform equally well despite better incorporation of individual soil properties within the continuous-PTFs. These results reinforced the significance of class-PTFs as developed by Bruand et al. (2003) that were based on texture alone or on both texture and clod bulk density, the latter giving the best performance. However, use of these class-PTFs has remained limited because clod bulk density is not available in most soil databases This study develops the study by Al Majou et al. (2007) for predicting volumetric water content at several water potentials by combining texture, bulk density and type of horizon. The validity of these class-PTFs was assessed at -33 
and $-1500 \mathrm{kPa}$ water potential and the class-PTFs developed in this study were used to derive maps of available water capacity for France.

\section{MATERIAL AND METHODS}

\section{Data collection}

Class-PTFs were developed using a set of 456 horizons comprising 138 topsoil horizons (from 0 to $30 \mathrm{~cm}$ depth) and 318 subsoil horizons (> $30 \mathrm{~cm}$ depth) collected from Cambisols, Luvisols, Planosols, Albeluvisols, Podzols and Fluvisols (ISSS Working Group WRB, 1998) located in the Paris basin, Brittany, the western coastal marshlands and Pyrenean piedmont plain (Figure 1a). A set of 197 horizons from Cambisols, Luvisols and Fluvisols (ISSS Working Group WRB, 1998), from several areas of France and developed on a large range of parent materials was collated in order to test the derived class-PTFs (Figure 1b).

\section{Basic and water retention properties}

Particle size distribution was measured using the pipette method after pre-treatment with hydrogen peroxide and sodium hexametaphosphate (Robert \& Tessier 1974). The soil textural triangle of the Commission of the European Communities was used to derive classes (Commission of the European Communities, 1985) (Figure 2). The cation exchange capacity $\left(\mathrm{cmol}_{\mathrm{c}} \mathrm{kg}^{-1}\right.$ of oven-dried soil) was measured using the cobalt-hexamine trichloride method (Ciesielski \& Sterckeman 1997) and organic carbon by oxidation using excess potassium dichromate in sulphuric acid at $135^{\circ} \mathrm{C}$ (Baize 2000). Bulk density $\left(D_{b}\right)$ was measured by using

cylinders $1236 \mathrm{~cm}^{3}$ in volume taken when the soil was near to field capacity. The gravimetric water content was determined by using pressure plate apparatus for the 456 horizons data set at $-1,-3.3,-10,-33,-100,-330$ and $-1500 \mathrm{kPa}$ water potential, and for the 197 horizon data 
set at -33 and $-1500 \mathrm{kPa}$ water potential, by using undisturbed samples $\left(10-15 \mathrm{~cm}^{3}\right)$ collected when the soil was near to field capacity for both sets (Bruand and Tessier, 2000). Then, the volumetric water content $(\theta)$ for each horizon was computed using the bulk density of horizon (Table 1).

\section{Analysis of the class-PTFs performance}

Most discussions of PTFs performance are based the root mean square error (RMSE), also called root mean squared deviation or root mean square residual (Wösten et al., 2001). Because RMSE varies according to both prediction bias and precision, we also computed the mean error of prediction $(M E P)$ to enable discussion of prediction bias and the standard deviation of prediction $(S D P)$ for assessment of prediction precision. Thus we computed the RMSE, MEP and SDP at -33 and $-1500 \mathrm{kPa}$ water potential as following:

$$
\begin{gathered}
R M S E=\left\{\frac{1}{l^{\prime} \cdot l} \sum_{j=1}^{l^{\prime}} \sum_{i=1}^{l}\left(\theta_{p, j, i}-\theta_{m, j, i}\right)^{2}\right\}^{1 / 2} \\
M E P=\frac{1}{l^{\prime} \cdot l} \sum_{j=1}^{l^{\prime}} \sum_{i=1}^{l}\left(\theta_{p, j, i}-\theta_{m, j, i}\right) \\
S D P=\left\{\frac{1}{l^{\prime} \cdot l} \sum_{j=1}^{l^{\prime}} \sum_{i=1}^{l}\left[\left(\theta_{p, j, i}-\theta_{m, j, i}\right)-M E P\right]^{2}\right\}^{1 / 2}
\end{gathered}
$$

where ${ }_{p, j, i}$ is the predicted water content at potential $i$ for horizon $j$, ? ${ }_{m, i, j}$ is the measured water content at potential $i$ for horizon $j$, and $l$ is the number of water potentials for each horizon ( $l=7$ in this study) and $l^{\prime}$ is the number of horizons $\left(l^{\prime} \leq 197\right.$ in this study). The MEP corresponds to the bias and indicates whether the class-PTFs overestimated (positive) or underestimated (negative) the water content, whereas SDP measures the precision of the prediction. 


\section{RESULTS AND DISCUSSION}

\section{Deriving the class-PTFs}

The class-PTFs developed in this study comprised average water content at seven water potentials. They were first established according to the soil texture classes (texture classPTFs) used by the Commission of European Communities (1985) for all horizons (Table 2). Then, as topsoils and subsoils often have different pore size distribution particularly with respect to macroporosity, texture class-PTFs were also developed after stratification by type of horizon (topsoil and subsoil horizons) (Table 3). Then, due to differences in bulk density $\left(D_{b}\right)$, class-PTFs were established according to both texture and $D_{b}$ (texture-structural classPTFs) for the whole set of horizons without any other stratification (Table 4) and also after stratification by the type of horizon (topsoil and subsoil horizons) (Table 5).

\section{Validity of the textural and texturo-structural class-PTFs}

The texture class-PTFs underestimated water retained $\left(M E P=-0.015 \mathrm{~cm}^{3} . \mathrm{cm}^{-3}\right)$ when applied to the test dataset (Table 6). The precision of the estimation was small with $S D P=$ $0.041 \mathrm{~cm}^{3} \cdot \mathrm{cm}^{-3}$. There was a $0.011 \mathrm{~cm}^{3} \cdot \mathrm{cm}^{-3}$ decrease in the prediction bias and a 0.009 $\mathrm{cm}^{3} . \mathrm{cm}^{-3}$ increase in the precision with texture-structural class-PTFs. With the texture classPTFs, the greatest bias and the least precision were recorded for the Fine texture class $(M E P=$ $-0.025 \mathrm{~cm}^{3} \cdot \mathrm{cm}^{-3}$ and $\left.S D P=0.042 \mathrm{~cm}^{3} . \mathrm{cm}^{-3}\right)$, and the improvement in estimation performance was particularly significant for that texture with the texture-structural class-PTFs $(M E P=-$ $0.005 \mathrm{~cm}^{3} \cdot \mathrm{cm}^{-3}$ and $\left.S D P=0.032 \mathrm{~cm}^{3} \cdot \mathrm{cm}^{-3}\right)$. Therefore, the high RMSE recorded with the texture class-PTFs $\left(R M S E=0.044 \mathrm{~cm}^{3} \cdot \mathrm{cm}^{-3}\right)$ was related to a relatively poor prediction precision $\left(S D P=0.041 \mathrm{~cm}^{3} \cdot \mathrm{cm}^{-3}\right)$, the bias being small $\left(M E P=-0.015 \mathrm{~cm}^{3} \cdot \mathrm{cm}^{-3}\right)$. However, 
this RMSE was smaller than the RMSE recorded by Bruand et al. (2003) for volumetric water content with texture class-PTFs that enabled prediction of the gravimetric water content at -33 and $-1500 \mathrm{kPa}$ water potential. The smaller RMSE recorded with the texture-structural classPTFs $\left(\triangle R M S E=0.011 \mathrm{~cm}^{3} . \mathrm{cm}^{-3}\right)$ was related to the significant decrease in the estimation bias and increase in precision. The RMSE recorded with the texture-structural class-PTFs was again smaller than the RMSE recorded by Bruand et al. (2003) for the volumetric water content with texture-structural class-PTFs developed in their study.

Validity of the texture and texture-structural class-PTFs after stratification by horizon type

Establishing textural class-PTFs after stratification according to the type of horizon (i.e. by separating topsoil and subsoil horizons) did not improve the performance of the texture class-PTFs $\left(\triangle M E P=0.001 \mathrm{~cm}^{3} \cdot \mathrm{cm}^{-3}\right.$ and $\left.\triangle S D P=0.002 \mathrm{~cm}^{3} . \mathrm{cm}^{-3}\right)($ Table 6). There was also no improvement in the performance with the texture-structural class-PTFs after stratification by horizon type $\left(\triangle M E P=0.001 \mathrm{~cm}^{3} \cdot \mathrm{cm}^{-3}\right.$ and $\left.\triangle S D P=0.003 \mathrm{~cm}^{3} \cdot \mathrm{cm}^{-3}\right)($ Table 6). This lack of improvement explains the similar RMSE that were recorded with the texture and texturestructural class-PTFs with or without stratification by horizon type (Table 6).

\section{Validity of the texture and texture-structural class-PTFs according to water potential}

Analysis of the results according to water potential showed that each type of class-PTF studied led to roughly similar performance at -33 and $-1500 \mathrm{kPa}$ (Figure 3). The bias was however slightly improved at $-33 \mathrm{kPa}$ for each type of PTF discussed (Figure 3). On the other hand, the precision was a little greater and the RMSE smaller at $-1500 \mathrm{kPa}$ except for the texture-structural PTFs (Table 7). This weak difference in performance at -33 and $-1500 \mathrm{kPa}$ means similar performance in a large range of water potential for the discussed class-PTFs. 


\section{Application of class-PTFs to France}

Class-PTFs as developed in this study were used to compute available water capacity (AWC) for Soil Typological Units (STU) in the 1:1000 000 Soil Geographical Database of France (King et al., 1995). Available water was taken as the water held between wilting point $(-1500 \mathrm{kPa}$ water potential) and field capacity (-10 kPa water potential). A water potential of $10 \mathrm{kPa}$ was shown as the water potential at field capacity for the studied soil (Al Majou et al., 2008). The depth, texture and bulk density of the topsoils and subsoils were based on available descriptions of STU attributes (King et al., 1995). The amount of available water for each topsoil and subsoil was derived from the appropriate class-PTFs multiplied by the thickness of each horizon. Then, the total available water in mm for each STU was computed by summation of the corresponding topsoil and subsoil. Next, the available water in $\mathrm{mm}$ for each Soil Mapping Unit (SMU) was computed according to the proportion of the different STU present in each SMU (King et al., 1995; Wösten et al., 1999). A map of the AWC was established by using the texture-structural class-PTFs that showed the best performance (Table 4, Figure 4). The average AWC of $104 \mathrm{~mm}$ was computed for France by taking into account the surface area of each SMU.

\section{CONCLUSION}

Our results show that the best performing PTF was based on both texture and bulk density (texture-structural class-PTFs). It was also shown that incorporation of horizon type did not improve prediction performance. Comparison of the performance at -33 and $-1500 \mathrm{kPa}$ showed very little difference, thus indicating no bias according to value of water potential. Finally, the class-PTFs developed require little soil information and are well suited for predicting water retention properties at continental and national scales because only very basic soils data is available at these scales. This was illustrated with the use of the class-PTFs 
developed to generate a map of the available water capacity (AWC) for the whole of France using the 1:1000 000 Soil Geographical Database of France; as a result the average AWC was computed for France.

\section{REFERENCES}

Al Majou H Bruand A Duval O \& Cousin I 2007. Variation of the water retention properties of soils: validity of class-pedotransfer functions. Comptes Rendus. Geoscience, 339, 632639.

Al Majou H Bruand A \& Duval O 2008. Use of in situ volumetric water content at field capacity to improve prediction of soil water retention properties. Canadian Journal of Soil Science, In press.

Baize D 2000. Guide des analyses en pédologie. INRA Paris.

Bastet G Bruand A Voltz M Bornand M \& Quétin P 1999. Performance of available pedotransfer functions for predicting the water retention properties of French soils. In: M. Th. Van Genuchten, F.J. Leij, L. Wu (eds), Proceedings of the International Workshop on Characterization and Measurement of the Hydraulic Properties of Unsaturated Porous Media, Riverside, California, October 22-24, 981-992.

Bouma J \& van Lanen HAJ 1987. Transfer functions and threshold values: from soil characteristics to land qualities. p 106-111. In: Beek K.J., P.A. Burrough and D.E. McCormack (eds.), Proc. ISSS/SSSA Workshop on Quantified Land Evaluation Procedures. Int. Inst. for Aerospace Surv. and Earth Sci., Publ. No 6, Enschede, The Netherlands.

Bruand A Baize D \& Hardy M 1994. Prediction of water retention properties of clayey soils: validity of relationships using a single soil characteristic. Soil Use and Management, 10, 99-103. 
Bruand A Pérez Fernandez P \& Duval O 2003. Use of class pedotransfer functions based on texture and bulk density of clods to generate water retention curves. Soil Use and Management, 19, 232-242.

Bruand A Duval O \& Cousin I 2004. Estimation des propriétés de rétention en eau des sols à partir de la base de données SOLHYDRO: Une première proposition combinant le type d'horizon, sa texture et sa densité apparente. Etude et Gestion des Sols, 11, 323-334.

Bruand A \& Tessier D 2000. Water retention properties of the clay in soils developed on clayey sediments: Significance of parent material and soil history. European Journal of Soil Science, 51, 679- 688 .

Ciesielski H \& Sterckeman T 1997. Determination of cation exchange capacity and exchangeable cations in soils by means of cobalt hexamine trichloride. Effects of experimental conditions. Agronomie, 17, 1-7.

Commission of the European Communities 1985. Soil map of the European Communities. Scale 1:1 000 000, CEC-DGVI, Luxembourg.

Cornelis M Ronsyn J Van Meirvenne M \& Hartmann R 2001. Evaluation of Pedotransfer Functions for Predicting the Soil Moisture Retention Curve. Soil Sci. Soc. Am J. 65, 638648.

Donatelli M Wösten JH.M Belocchi G Acutis M Nemes A \& Fila G 2004. Methods to evaluate pedotransfer functions. Elsevier B.V. 30, 357-411.

ISSS Working Group RB 1998. World Reference Base for Soil Resources: Introduction (eds J.A. Deckers, F.O. Nachtergaele \& O.C. Spaargaren), First Ed. International Society of Soil Science (ISSS). ISRIC-FAO-ISSS-Acco. Leuven.

King D Burrill A Daroussin J Le Bas C Tavernier R \& Van Ranst E 1995. The EU soil geographical database. In: King, D., Jones, R.J.A., Thomasson, A.J. (Eds), European Land 
Information Systems for Agro-environmental Monitoring. JointResearch Centre, Ispra, Italy, 43-60.

Leenhardt D 1995. Errors in the estimation of soil water properties and their propagation through a hydrological model. Soil Use and Management, 11, 15-21.

Lilly A Wösten JHM Nemes A \& Le Bas C 1999. The development and use of the HYPRES database in Europe. In: MTh van Genuchten \& FJ Leij, eds, Characterization and measurement of the hydraulic properties of unsaturated porous media. Proceedings of the International Workshop Riverside, California, October 22-24, 1997 pp 1283-1204.

Nemes A 2002. Unsaturated soil hydraulic database of Hungary: HUNSODA. Agrokémia és Talajtan, 51, 17-26.

Nemes A Schaap MG \& Wösten JHM 2003. Functions evaluation of pedotransfer functions derived from different scales of data collection. Soil Science Society of America Journal, 67, 1093-1102.

Minasny B McBratney AB \& Bristow KL 1999. Comparison of different approaches to the development of pedotransfer functions for water-retention curves. Geoderma, 93, 225-253.

Pachepsky YA \& Rawls WJ 1999. Accuracy and reliability of pedotransfer functions as affected by grouping soils. Soil Sci. Soc. Am. J. 63, 1748 - 1757.

Pachepsky YA \& Rawls WJ 2003. Soil structure pedotransfer functions. European Journal of Soil Science, 54, 443-451.

Pachepsky YA Rawls WJ \& Lin HS 2006. Hydropedology and pedotransfer functions. Geoderma. 131, 308-316.

Rawls WJ Brakensiek DL \& Saxton KE 1982. Estimation of soil water properties. Trans. ASAE, 26, 1747-1752.

Rawls WJ Pachepsky YA Ritchie JC Sobecki T.M \& Bloodworth H 2003. Effect of soil organic carbon on soil water retention. Geoderma 116, 61-76. 
Rawls WJ Nemes A \& Pachepsky YA 2004. Effect of soil organic carbon on soil hydraulic properties. Elsevier B.V. 30, 95-114.

Robert M \& Tessier D 1974. Méthode de préparation des argiles des sols pour les études minéralogiques. Annales Agronomiques, 25, 859-882.

Tranter G Minasny B McBratney AB Murphy B Mckenzie NJ Grundy M Brough D 2007. Building and testing conceptual and empirical models for predicting soil bulk density. Soil Use and Management, 23, 437-443.

Vereecken H Maes J Feyen J \& Darius P 1989. Estimating the soil moisture retention characteristics from texture, bulk density and carbon content. Soil Science 148, 389-403.

Ungaro F Calzolari C \& Busoni E 2005. Development of pedotransfer functions using a group method of handling for the soil of the Pianura Padano-Veneta region of North Italy: waterretention properties, Geoderma 124, 293-317.

Wösten JHM Finke PA \& Jansen MJW 1995. Comparison of class and continuous pedotransfer functions to generate soil hydraulic characteristics. Geoderma, 66, 227-237.

Wösten JHM Lilly A Nemes A \& Le Bas C 1999. Development and use of a database of hydraulic properties of European soils. Geoderma, 90, 169-185.

Wösten JHM Pachepsky YA \& Rawls WJ 2001. Pedotransfer functions: bridging the gap between available basic soil data missing soil hydraulic characteristics. Journal of hydrology, 251, 123-150. 


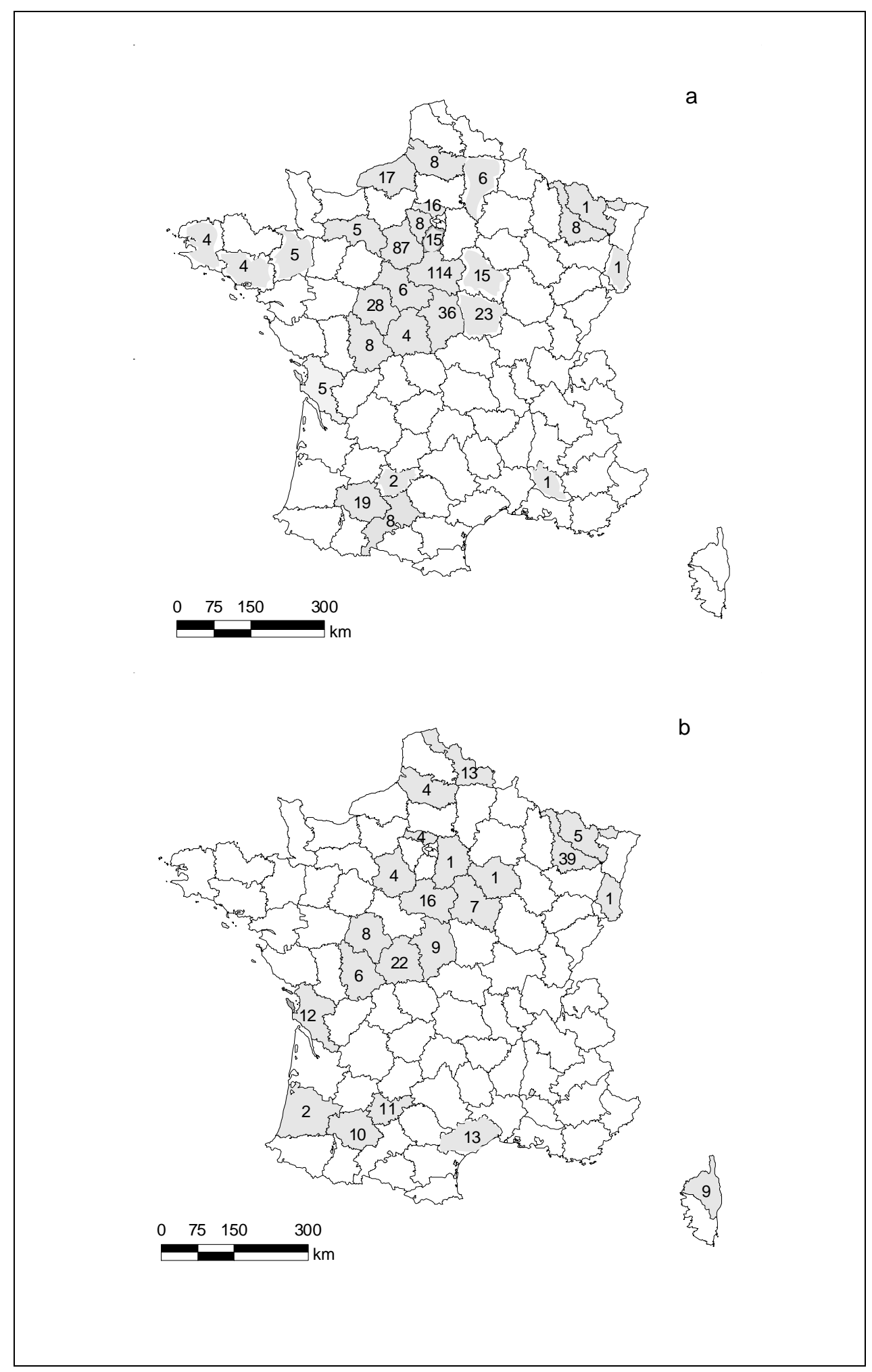

Figure 1. Location of the studied soils (number of horizon by department) that were used to establish the classPTFs (a) and to test their validity (b). 

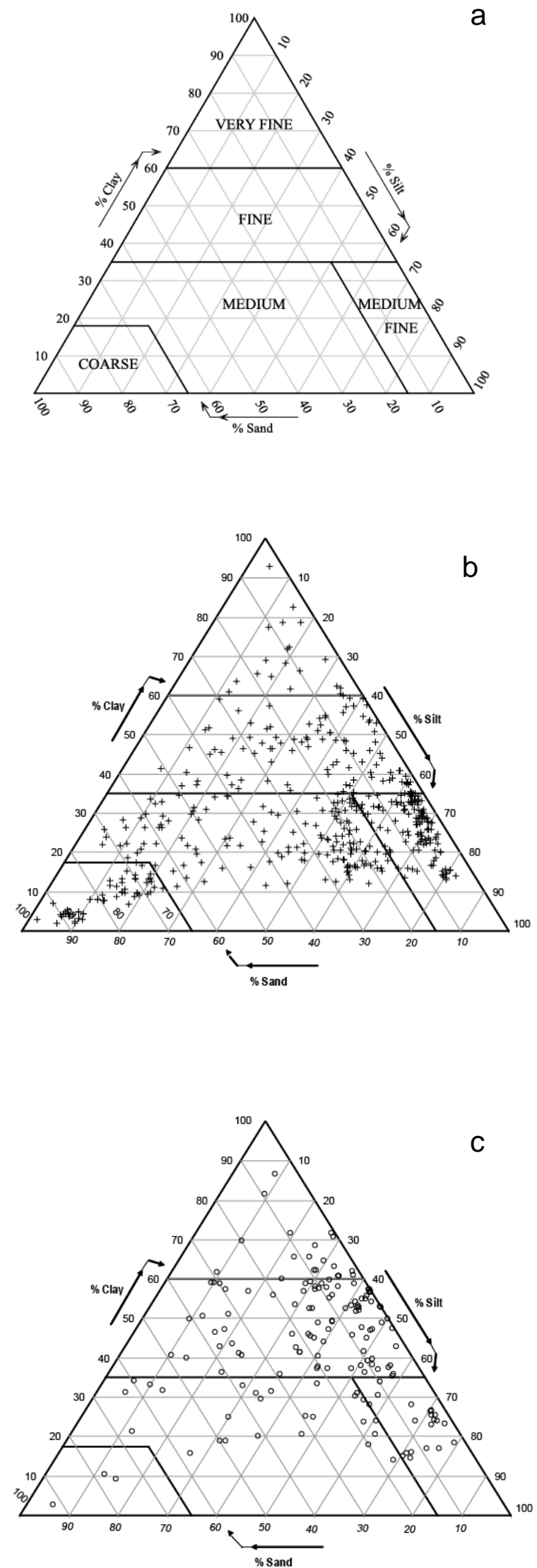

Figure 2. Texture triangle used (a), texture of the horizons used to establish the class-PTFs (b) and texture of those used to test their validity $(\mathrm{c})$. 


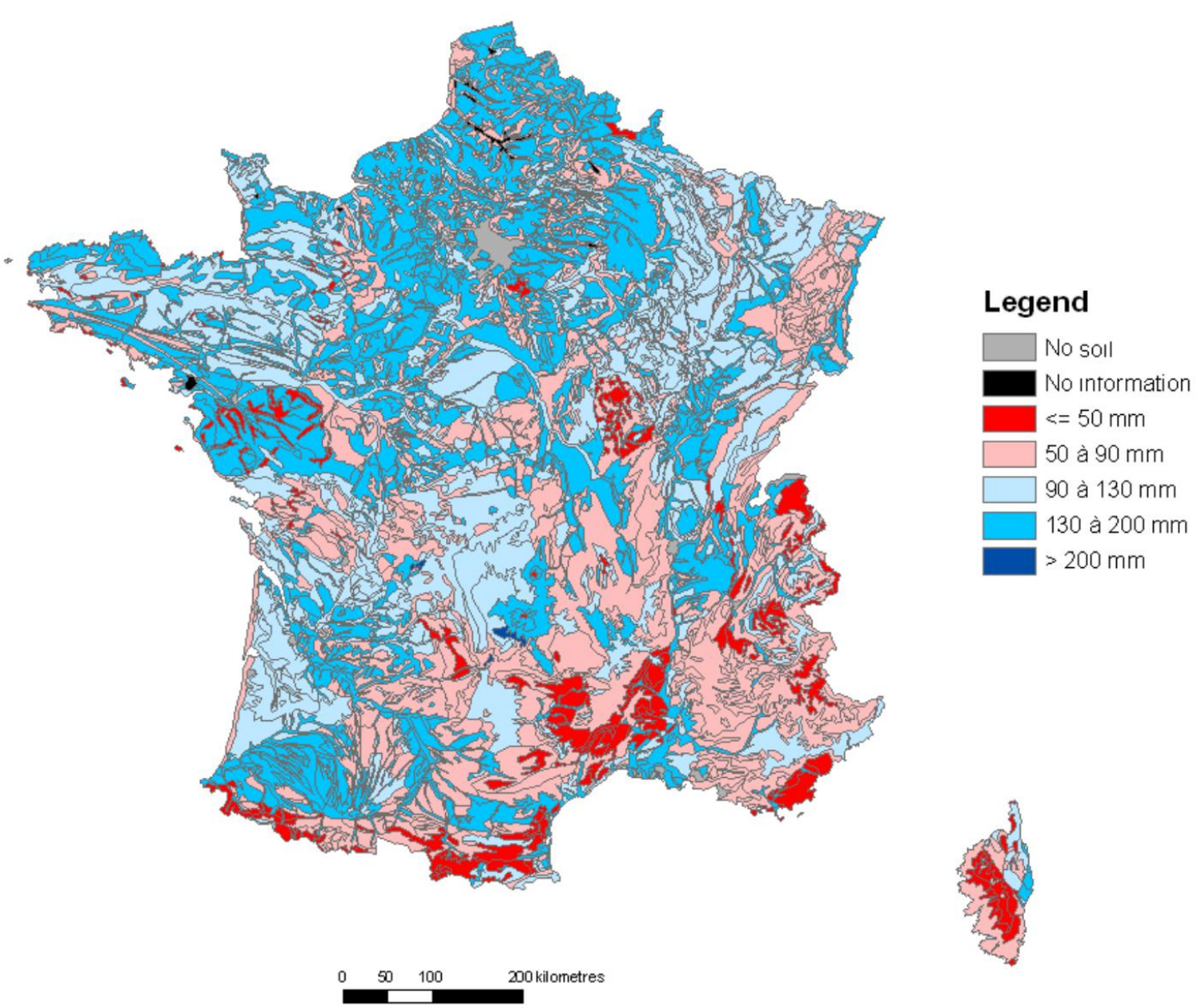

Figure 3. Available water capacity (mm) for France using the texture-structural class-PTFs. 
Table 1. Characteristics of the horizons used to establish the PTFs.

\begin{tabular}{|c|c|c|c|c|c|c|c|c|c|c|c|c|c|c|}
\hline & \multicolumn{3}{|c|}{$\begin{array}{l}\text { Particle size } \\
\text { distribution }(\%)\end{array}$} & \multirow{2}{*}{$\begin{array}{l}\begin{array}{l}\text { Organic } \\
\text { carbon } \\
\text { content }\end{array} \\
\text { g.kg-1 } \\
\end{array}$} & \multirow{2}{*}{$\begin{array}{l}\begin{array}{l}\text { Calcium } \\
\text { carbonate } \\
\text { content }\end{array} \\
\text { g. } \mathrm{kg}^{-1} \\
\end{array}$} & \multirow{2}{*}{ 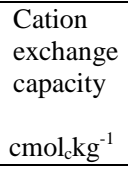 } & \multirow{2}{*}{$\begin{array}{l}\text { Bulk } \\
\text { Density } \\
\text { g.cm } \\
\end{array}$} & \multicolumn{7}{|c|}{ Volumetric water content $\left(\mathrm{cm}^{3} \cdot \mathrm{cm}^{-3}\right)$} \\
\hline & $\begin{array}{l}<2 \\
\mu \mathrm{m}\end{array}$ & $\begin{array}{l}2-50 \\
\mu \mathrm{m}\end{array}$ & $\begin{array}{l}50- \\
2000 \\
\mu \mathrm{m} \\
\end{array}$ & & & & & $\theta_{1}$ & $\theta_{3.3}$ & $\theta_{10}$ & $\theta_{33}$ & $\theta_{100}$ & $\theta_{330}$ & $\theta_{1500}$ \\
\hline \multicolumn{15}{|c|}{ Horizons used to derive the class-PTFs $(n=456)$} \\
\hline mean & 29.3 & 43.8 & 26.9 & 6.0 & 54.2 & 14.8 & 1.52 & 0.354 & 0.335 & 0.315 & 0.289 & 0.259 & 0.221 & 0.187 \\
\hline s.d. & 15.4 & 21.8 & 25.6 & 5.1 & 171.3 & 9.0 & 0.15 & 0.068 & 0.070 & 0.075 & 0.076 & 0.079 & 0.076 & 0.073 \\
\hline $\min$. & 1.9 & 1.6 & 0.1 & 0.0 & 0.0 & 0.6 & 0.95 & 0.134 & 0.100 & 0.080 & 0.056 & 0.045 & 0.033 & 0.013 \\
\hline $\max$. & 92.9 & 82.1 & 95.4 & 28.8 & 982 & 52.8 & 1.98 & 0.605 & 0.596 & 0.586 & 0.557 & 0.510 & 0.462 & 0.370 \\
\hline \multicolumn{15}{|c|}{ Horizons used to test the class-PTFs $(n=197)$} \\
\hline mean & 39.4 & 39.3 & 21.3 & 5.6 & 31.5 & 19.9 & 1.45 & - & - & - & 0.330 & - & - & 0.235 \\
\hline s.d. & 16.9 & 17.1 & 19.2 & 5.8 & 58.7 & 7.8 & 0.16 & - & - & - & 0.071 & - & - & 0.070 \\
\hline $\min$ & 2.7 & 5.4 & 0.0 & 0.0 & 0.0 & 3.3 & 1.16 & - & - & - & 0.107 & - & - & 0.065 \\
\hline max. & 86.7 & 79.4 & 91.9 & 40.3 & 212.0 & 40.4 & 1.94 & - & - & - & 0.468 & - & - & 0.360 \\
\hline
\end{tabular}


Table 2. Texture class-PTFs.

\begin{tabular}{|c|c|c|c|c|c|c|c|}
\hline & \multicolumn{7}{|c|}{ Volumetric water content $\left(\mathrm{cm}^{3} \cdot \mathrm{cm}^{-3}\right)$} \\
\hline & $\theta_{1}$ & $\theta_{3.3}$ & $\theta_{10}$ & $\theta_{33}$ & $\theta_{100}$ & $\theta_{330}$ & $\theta_{1500}$ \\
\hline \multicolumn{8}{|c|}{ After stratification by texture alone $(n=456)$} \\
\hline Very fine $(\mathrm{n}=20)$ & 0.457 & 0.439 & 0.426 & 0.404 & 0.387 & 0.352 & 0.327 \\
\hline Fine $(n=102)$ & 0.405 & 0.390 & 0.374 & 0.351 & 0.333 & 0.299 & 0.262 \\
\hline Medium fine $(\mathrm{n}=127)$ & 0361 & 0.345 & 0.329 & 0.300 & 0.257 & 0.211 & 0.178 \\
\hline Medium $(n=151)$ & 0.336 & 0.318 & 0.300 & 0.273 & 0.244 & 0.204 & 0.164 \\
\hline Coarse $(n=56)$ & 0.257 & 0.220 & 0.180 & 0.150 & 0.123 & 0.102 & 0.082 \\
\hline
\end{tabular}


Table 3. Texture class-PTFs developed according to type of horizon (topsoil and subsoil horizons).

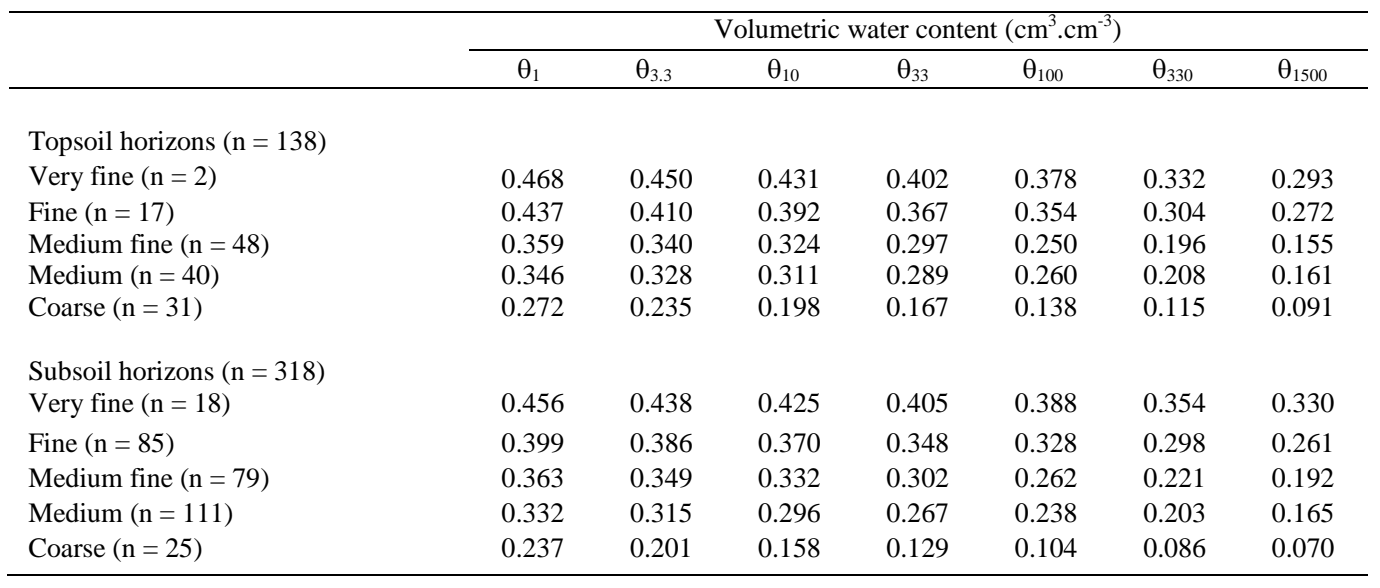


Table 4. Texture-structural class-PTFs.

\begin{tabular}{|c|c|c|c|c|c|c|c|c|c|}
\hline & & \multirow[t]{2}{*}{$n$} & \multicolumn{7}{|c|}{ Volumetric water content $\left(\mathrm{cm}^{3} . \mathrm{cm}^{-3}\right)$} \\
\hline & & & $\theta_{1}$ & $\theta_{3.3}$ & $\theta_{10}$ & $\theta_{33}$ & $\theta_{100}$ & $\theta_{330}$ & $\theta_{1500}$ \\
\hline \multirow{3}{*}{$\begin{array}{l}\text { Very fine } \\
(\mathrm{n}=20)\end{array}$} & $1.10 \leq \mathrm{D}_{\mathrm{b}}<1.30$ & 9 & 0.491 & 0.469 & 0.450 & 0.423 & 0.405 & 0.361 & 0.334 \\
\hline & $1.30 \leq \mathrm{D}_{\mathrm{b}}<1.50$ & 7 & 0.463 & 0.443 & 0.430 & 0.408 & 0.386 & 0.346 & 0.330 \\
\hline & $1.50 \leq \mathrm{D}_{\mathrm{b}}<1.70$ & 4 & 0.390 & 0.374 & 0.376 & 0.370 & 0.367 & 0.354 & 0.308 \\
\hline \multirow{4}{*}{$\begin{array}{l}\text { Fine } \\
(\mathrm{n}=102)\end{array}$} & $1.00 \leq \mathrm{D}_{\mathrm{b}}<1.20$ & 6 & 0.529 & 0.503 & 0.492 & 0.462 & 0.438 & 0.368 & 0.270 \\
\hline & $1.20 \leq \mathrm{D}_{\mathrm{b}}<1.40$ & 21 & 0.444 & 0.429 & 0.411 & 0.380 & 0.364 & 0.325 & 0.281 \\
\hline & $1.40 \leq \mathrm{D}_{\mathrm{b}}<1.60$ & 61 & 0.392 & 0.375 & 0.359 & 0.340 & 0.320 & 0.288 & 0.258 \\
\hline & $1.60 \leq \mathrm{D}_{\mathrm{b}}<1.80$ & 14 & 0.353 & 0.346 & 0.331 & 0.309 & 0.295 & 0.278 & 0.249 \\
\hline \multirow{3}{*}{$\begin{array}{l}\text { Medium fine } \\
(\mathrm{n}=127)\end{array}$} & $1.20 \leq \mathrm{D}_{\mathrm{b}}<1.40$ & 24 & 0.360 & 0.344 & 0.326 & 0.293 & 0.241 & 0.192 & 0.159 \\
\hline & $1.40 \leq \mathrm{D}_{\mathrm{b}}<1.60$ & 84 & 0.363 & 0.346 & 0.329 & 0.300 & 0.259 & 0.211 & 0.178 \\
\hline & $1.60 \leq \mathrm{D}_{\mathrm{b}}<1.80$ & 19 & 0.356 & 0.346 & 0.331 & 0.308 & 0.271 & 0.238 & 0.200 \\
\hline \multirow{4}{*}{$\begin{array}{l}\text { Medium } \\
(\mathrm{n}=151)\end{array}$} & $1.20 \leq \mathrm{D}_{\mathrm{b}}<1.40$ & 17 & 0.361 & 0.340 & 0.320 & 0.285 & 0.253 & 0.202 & 0.154 \\
\hline & $1.40 \leq \mathrm{D}_{\mathrm{b}}<1.60$ & 66 & 0.347 & 0.328 & 0.307 & 0.275 & 0.240 & 0.200 & 0.160 \\
\hline & $1.60 \leq \mathrm{D}_{\mathrm{b}}<1.80$ & 65 & 0.319 & 0.304 & 0.289 & 0.267 & 0.245 & 0.207 & 0.169 \\
\hline & $1.80 \leq \mathrm{D}_{\mathrm{b}}<2.00$ & 3 & 0.296 & 0.294 & 0.276 & 0.273 & 0.269 & 0.245 & 0.209 \\
\hline \multirow{4}{*}{$\begin{array}{l}\text { Coarse } \\
(n=56)\end{array}$} & $1.20 \leq \mathrm{D}_{\mathrm{b}}<1.40$ & 6 & 0.255 & 0.200 & 0.175 & 0.136 & 0.114 & 0.094 & 0.076 \\
\hline & $1.40 \leq \mathrm{D}_{\mathrm{b}}<1.60$ & 20 & 0.254 & 0.208 & 0.163 & 0.137 & 0.111 & 0.092 & 0.078 \\
\hline & $1.60 \leq \mathrm{D}_{\mathrm{b}}<1.80$ & 26 & 0.262 & 0.239 & 0.199 & 0.167 & 0.138 & 0.113 & 0.088 \\
\hline & $1.80 \leq \mathrm{D}_{\mathrm{b}}<2.00$ & 4 & 0.237 & 0.181 & 0.153 & 0.127 & 0.100 & 0.091 & 0.065 \\
\hline
\end{tabular}


Table 5. Texture-structural class-PTFs developed according to type of horizon (topsoil and subsoil horizons).

\begin{tabular}{|c|c|c|c|c|c|c|c|c|c|}
\hline & & \multirow[t]{2}{*}{$n$} & \multicolumn{7}{|c|}{ Volumetric water content $\left(\mathrm{cm}^{3} \cdot \mathrm{cm}^{-3}\right)$} \\
\hline & & & $\theta_{1}$ & $\theta_{3.3}$ & $\theta_{10}$ & $\theta_{33}$ & $\theta_{100}$ & $\theta_{330}$ & $\theta_{1500}$ \\
\hline \multicolumn{10}{|c|}{ Topsoil horizons $(\mathrm{n}=138)$} \\
\hline Very fine & $1.10 \leq \mathrm{D}_{\mathrm{b}}<1.30$ & 2 & 0.468 & 0.450 & 0.431 & 0.402 & 0.378 & 0.332 & 0.293 \\
\hline \multirow[t]{3}{*}{ Fine $(n=17)$} & $1.00 \leq \mathrm{D}_{\mathrm{b}}<1.20$ & 2 & 0.468 & 0.422 & 0.402 & 0.383 & 0.376 & 0.312 & 0.280 \\
\hline & $1.20 \leq \mathrm{D}_{\mathrm{b}}<1.40$ & 6 & 0.453 & 0.431 & 0.410 & 0.382 & 0.378 & 0.324 & 0.293 \\
\hline & $1.40 \leq \mathrm{D}_{\mathrm{b}}<1.60$ & 9 & 0.420 & 0.394 & 0.377 & 0.354 & 0.332 & 0.289 & 0.256 \\
\hline \multirow{2}{*}{$\begin{array}{l}\text { Medium fine } \\
(\mathrm{n}=48)\end{array}$} & $1.20 \leq \mathrm{D}_{\mathrm{b}}<1.40$ & 19 & 0.358 & 0.343 & 0.325 & 0.294 & 0.239 & 0.189 & 0.153 \\
\hline & $1.40 \leq \mathrm{D}_{\mathrm{b}}<1.60$ & 29 & 0.360 & 0.338 & 0.324 & 0.299 & 0.257 & 0.200 & 0.156 \\
\hline \multirow{3}{*}{$\begin{array}{l}\text { Medium } \\
(\mathrm{n}=40)\end{array}$} & $1.20 \leq \mathrm{D}_{\mathrm{b}}<1.40$ & 11 & 0.372 & 0.353 & 0.335 & 0.302 & 0.270 & 0.214 & 0.164 \\
\hline & $1.40 \leq \mathrm{D}_{\mathrm{b}}<1.60$ & 20 & 0.349 & 0.328 & 0.311 & 0.294 & 0.265 & 0.215 & 0.171 \\
\hline & $1.60 \leq \mathrm{D}_{\mathrm{b}}<1.80$ & 9 & 0.308 & 0.295 & 0.281 & 0.261 & 0.236 & 0.186 & 0.133 \\
\hline \multirow{3}{*}{$\begin{array}{l}\text { Coarse } \\
(n=31)\end{array}$} & $1.20 \leq \mathrm{D}_{\mathrm{b}}<1.40$ & 5 & 0.265 & 0.206 & 0.178 & 0.146 & 0.120 & 0.100 & 0.077 \\
\hline & $1.40 \leq \mathrm{D}_{\mathrm{b}}<1.60$ & 13 & 0.258 & 0.210 & 0.171 & 0.148 & 0.120 & 0.098 & 0.085 \\
\hline & $1.60 \leq \mathrm{D}_{\mathrm{b}}<1.80$ & 13 & 0.290 & 0.271 & 0.234 & 0.195 & 0.164 & 0.136 & 0.103 \\
\hline \multicolumn{10}{|c|}{ Subsoil horizons $(\mathrm{n}=318)$} \\
\hline \multirow{3}{*}{$\begin{array}{l}\text { Very fine } \\
(\mathrm{n}=18)\end{array}$} & $1.10 \leq \mathrm{D}_{\mathrm{b}}<1.30$ & 8 & 0.487 & 0.463 & 0.445 & 0.421 & 0.406 & 0.367 & 0.344 \\
\hline & $1.30 \leq \mathrm{D}_{\mathrm{b}}<1.50$ & 7 & 0.463 & 0.443 & 0.430 & 0.408 & 0.386 & 0.346 & 0.330 \\
\hline & $1.50 \leq \mathrm{D}_{\mathrm{b}}<1.70$ & 3 & 0.378 & 0.370 & 0.378 & 0.374 & 0.371 & 0.354 & 0.295 \\
\hline \multirow{4}{*}{$\begin{array}{l}\text { Fine } \\
(n=85)\end{array}$} & $1.00 \leq \mathrm{D}_{\mathrm{b}}<1.20$ & 4 & 0.560 & 0.544 & 0.536 & 0.502 & 0.469 & 0.396 & 0.265 \\
\hline & $1.20 \leq \mathrm{D}_{\mathrm{b}}<1.40$ & 15 & 0.440 & 0.429 & 0.411 & 0.379 & 0.358 & 0.325 & 0.276 \\
\hline & $1.40 \leq \mathrm{D}_{\mathrm{b}}<1.60$ & 52 & 0.387 & 0.372 & 0.356 & 0.337 & 0.318 & 0.287 & 0.259 \\
\hline & $1.60 \leq \mathrm{D}_{\mathrm{b}}<1.80$ & 14 & 0.353 & 0.346 & 0.331 & 0.309 & 0.295 & 0.278 & 0.249 \\
\hline \multirow{3}{*}{$\begin{array}{l}\text { Medium fine } \\
(\mathrm{n}=79)\end{array}$} & $1.20 \leq \mathrm{D}_{\mathrm{b}}<1.40$ & 5 & 0.366 & 0.349 & 0.331 & 0.291 & 0.249 & 0.207 & 0.180 \\
\hline & $1.40 \leq \mathrm{D}_{\mathrm{b}}<1.60$ & 55 & 0.365 & 0.350 & 0.332 & 0.301 & 0.259 & 0.217 & 0.190 \\
\hline & $1.60 \leq \mathrm{D}_{\mathrm{b}}<1.80$ & 19 & 0.356 & 0.346 & 0.331 & 0.308 & 0.271 & 0.238 & 0.200 \\
\hline \multirow{4}{*}{$\begin{array}{l}\text { Medium } \\
(\mathrm{n}=111)\end{array}$} & $1.20 \leq \mathrm{D}_{\mathrm{b}}<1.40$ & 6 & 0.340 & 0.317 & 0.293 & 0.254 & 0.222 & 0.179 & 0.134 \\
\hline & $1.40 \leq \mathrm{D}_{\mathrm{b}}<1.60$ & 46 & 0.346 & 0.328 & 0.306 & 0.267 & 0.228 & 0.194 & 0.154 \\
\hline & $1.60 \leq \mathrm{D}_{\mathrm{b}}<1.80$ & 56 & 0.321 & 0.305 & 0.290 & 0.268 & 0.246 & 0.211 & 0.175 \\
\hline & $1.80 \leq \mathrm{D}_{\mathrm{b}}<2.00$ & 3 & 0.296 & 0.294 & 0.276 & 0.273 & 0.269 & 0.245 & 0.209 \\
\hline \multirow{3}{*}{$\begin{array}{l}\text { Coarse } \\
(n=25)\end{array}$} & $1.40 \leq \mathrm{D}_{\mathrm{b}}<1.60$ & 8 & 0.241 & 0.199 & 0.150 & 0.114 & 0.093 & 0.077 & 0.066 \\
\hline & $1.60 \leq \mathrm{D}_{\mathrm{b}}<1.80$ & 13 & 0.235 & 0.207 & 0.164 & 0.139 & 0.112 & 0.089 & 0.073 \\
\hline & $1.80 \leq \mathrm{D}_{\mathrm{b}}<2.00$ & 4 & 0.237 & 0.181 & 0.153 & 0.127 & 0.100 & 0.091 & 0.065 \\
\hline
\end{tabular}


Table 6. Validity of the class pedotranfer functions derived after stratification by texture alone, after stratification by texture and bulk density of horizon and according to the horizon.

\begin{tabular}{|c|c|c|c|c|}
\hline & $n$ & $\begin{array}{c}\text { Mean error of prediction } \\
(M E P) \\
\mathrm{cm}^{3} \cdot \mathrm{cm}^{-3} \\
\end{array}$ & $\begin{array}{c}\text { Standard deviation of } \\
\text { prediction }(S D P) \\
\mathrm{cm}^{3} \cdot \mathrm{cm}^{-3} \\
\end{array}$ & $\begin{array}{c}\text { Root mean squared error } \\
(R M S E) \\
\mathrm{cm}^{3} \cdot \mathrm{cm}^{-3} \\
\end{array}$ \\
\hline \multicolumn{5}{|l|}{ Texture class-PTFs } \\
\hline Very fine & 18 & -0.005 & 0.026 & 0.026 \\
\hline Fine & 98 & -0.025 & 0.042 & 0.049 \\
\hline Medium fine & 22 & -0.004 & 0.035 & 0.035 \\
\hline Medium & 51 & -0.007 & 0.043 & 0.044 \\
\hline Coarse & 8 & 0.003 & 0.021 & 0.020 \\
\hline All textures together & 197 & -0.015 & 0.041 & 0.044 \\
\hline \multicolumn{5}{|c|}{ Texture-structural class-PTFs } \\
\hline Very fine & 18 & 0.003 & 0.024 & 0.024 \\
\hline Fine & 98 & -0.005 & 0.032 & 0.032 \\
\hline Medium fine & 22 & -0.0003 & 0.036 & 0.036 \\
\hline Medium & 51 & -0.005 & 0.036 & 0.037 \\
\hline Coarse & 8 & -0.005 & 0.014 & 0.015 \\
\hline All textures together & 197 & -0.004 & 0.032 & 0.033 \\
\hline \multicolumn{5}{|c|}{ Textural class-PTFs after stratification by the type of horizon } \\
\hline Very fine & 18 & -0.003 & 0.026 & 0.026 \\
\hline Fine & 98 & -0.026 & 0.043 & 0.050 \\
\hline Medium fine & 22 & 0.002 & 0.037 & 0.037 \\
\hline Medium & 51 & -0.005 & 0.046 & 0.046 \\
\hline Coarse & 8 & 0.012 & 0.019 & 0.022 \\
\hline All textures together & 197 & -0.014 & 0.043 & 0.045 \\
\hline \multicolumn{5}{|c|}{ Texture-structural class-PTFs after stratification by type of horizon } \\
\hline Very fine & 18 & 0.004 & 0.026 & 0.026 \\
\hline Fine & 98 & -0.007 & 0.032 & 0.032 \\
\hline Medium fine & 22 & 0.003 & 0.037 & 0.037 \\
\hline Medium & 51 & -0.003 & 0.043 & 0.043 \\
\hline Coarse & 8 & 0.003 & 0.013 & 0.013 \\
\hline All textures together & 197 & -0.003 & 0.035 & 0.035 \\
\hline
\end{tabular}

${ }^{1}$ Volumetric water content at water potential h $\left(\theta_{\log \mid \mathrm{h} /}\right)$ 
Table 7. Validity of the texture and texture-structural class pedotranfer functions according to water potential (test dataset: $n=197$ ).

\begin{tabular}{|c|c|c|c|c|c|c|}
\hline & \multicolumn{2}{|c|}{$\begin{array}{c}\text { Mean error of prediction } \\
(M E P) \\
\mathrm{cm}^{3} \cdot \mathrm{cm}^{-3} \\
\end{array}$} & \multicolumn{2}{|c|}{$\begin{array}{c}\text { Standard deviation of } \\
\text { prediction }(S D P) \\
\mathrm{cm}^{3} \cdot \mathrm{cm}^{-3} \\
\end{array}$} & \multicolumn{2}{|c|}{$\begin{array}{c}\text { Root mean squared error } \\
(R M S E) \\
\mathrm{cm}^{3} \cdot \mathrm{cm}^{-3}\end{array}$} \\
\hline & $-33 \mathrm{kPa}$ & $-1500 \mathrm{kPa}$ & $-33 \mathrm{kPa}$ & $-1500 \mathrm{kPa}$ & $-33 \mathrm{kPa}$ & $-1500 \mathrm{kPa}$ \\
\hline $\begin{array}{l}\text { Texture class-PTFs } \\
\text { All textures together } \\
\text { according to the water } \\
\text { potential }\end{array}$ & -0.016 & -0.015 & 0.042 & 0.039 & 0.045 & 0.042 \\
\hline $\begin{array}{l}\text { Texture-structural class } \\
\text { All textures together } \\
\text { according to the water } \\
\text { potential }\end{array}$ & -0.003 & -0.005 & 0.033 & 0.032 & 0.033 & 0.033 \\
\hline $\begin{array}{l}\text { Texture class-PTFs afte } \\
\text { All textures together } \\
\text { according to the water } \\
\text { potential }\end{array}$ & $\begin{array}{l}\text { tion by ty } \\
-0.015\end{array}$ & $\begin{array}{l}\text { horizon } \\
-0.013\end{array}$ & 0.045 & 0.041 & 0.047 & 0.043 \\
\hline $\begin{array}{l}\text { Texture-structural class } \\
\text { All textures together } \\
\text { according to the water } \\
\text { potential }\end{array}$ & r stratific & $\begin{array}{l}\text { by type of } h \\
-0.005\end{array}$ & 0.034 & 0.035 & 0.034 & 0.035 \\
\hline
\end{tabular}

